\title{
SEBUTAN DAN SAPAAN DALAM ISTILAH \\ KEKERABATAN BAHASA TONTEMBOAN \\ SUATU KAJIAN LINGUISTIK ANTROPOLOGI
}

\author{
Oleh: Stelnie H. Perutu ${ }^{6}$
}

\begin{abstract}
The research about naming and addressing in Tontemboan Language Kinship Terminology is necessary and still relevant nowadays due to a lot of supporting factors for the language resistance such as attitude and appreciation which are about to be forgotten by the Minahasans. In fact, the director of Kawan Pustaka (2004:30) said that "the culture identity.... is respected along with the changing of the time and civilization". The culture identity includes the language. The method which is used in this research is qualitative method. This research is located in Motoling Timur district, Motoling Barat district, and Kumelembuai district, the south east of Minahasa. The results of this research are some blood relationship kinship terminologies such as inang, amang, bu , susi , mom, nene, tete, nene kundu, tete kundu, apo, toya $\square$ ang luluna, toya ang karuwa, toya ang, uner, toya $\square$ ang wobas, pakakaan, tuwari. and some in laws terminologies such as penanaan, ambalesa, kalo, kawuleng, kasule, kalaley, kasungku. The conclusion of this research is that the native speakers of Tontemboan language know the blood-relationship kinship terminology, the in laws terminology, and the additional kinship terminology. The collected data functions as naming, addressing and naming as well as addressing. Furthermore, those terminologies contain the cultural meaning.
\end{abstract}

Key words: kinship, naming, addressing, marriage- relationship, bloodrelationship.

\footnotetext{
${ }^{6}$ Peneliti Balai Bahasa Provinsi Sulawesi Utara
} 


\section{Pendahuluan}

Bahasa adalah salah satu alat komunikasi sekaligus penanda sosial (Alwasilah, 2007:9) yang sangat dibutuhkan oleh manusia. Tanpa bahasa, kehidupan akan terasa gersang dan mandul. Dengan bahasa, kita akan dapat melihat bagaimana sikap, pola kehidupan, cara berpikir sebuah komunitas ataupun jati diri seseorang, masyarakat, dan bangsa.

Redaksi Kawan Pustaka (2004:30) menjelaskan bahwa identitas budaya ... dihormati selaras dengan perkembangan zaman dan peradaban. Dalam pemahaman ini tersirat bahwa bahasa adalah bagian dari budaya yang diartikan sebagai pengetahuan yang diperoleh secara sosial (Cahyono, 1995:409) pun merupakan salah satu identitas budaya yang harus dihormati; termasuk di dalamnya bahasa daerah.

Bahasa Tontemboan adalah salah satu identitas budaya yang ada di daerah Minahasa-dulunya disebut Malesung (Wenas, 2007:1), harus dihormati juga. Selanjutnya, bahasa Tontemboan adalah bahasa yang dipakai oleh orang Minahasa yang menamai komunitas mereka orang Tontemboan.

Masalah dalam tulisan ini adalah 1) apa saja istilah kekerabatan dalam bahasa Tontemboan?, 2) sebutan dan sapaan apa yang digunakan dalam bahasa Tontemboan?, 3) makna budaya apa saja yang dikandung oleh setiap istilah kekerabatan dalam bahasa Tontemboan?Selanjutnya, penelitian ini bertujuan untuk 1) mengidentifikasi istilah kekerabatan dalam bahasa Tontemboan, 2) mengidentifikasi sebutan dan sapaan dalam istilah kekerabatan bahasa Tontemboan, dan 3) menjelaskan makna budaya apa saja yang dikandung oleh setiap istilah kekerabatan dalam bahasa Tontemboan.

Secara teoretis, manfaat penelitian ini memperkuat salah satu dalam kajian linguistik antropologi mengenai istilah kekerabatan hubungan darah dan istilah kekerabatan perkawinan yang dikelompokkan sebagai sebutan dan sapaan. Penelitian ini menjelaskan juga tentang makna budaya yang dikandung oleh setiap istilah kekerabatan tersebut.

Secara praktis, penelitian mengenai istilah kekerabatan bahasa Tontemboan dalam penelitian ini menjadi salah satu alat pelestari bahasa daerah khususnya bahasa Tontemboan, agar terhindar dari kepunahan karena pengaruh iptek yang mengglobal dan 
pengaruh moderenisasi yang sangat deras di daerah ini. Selanjutnya, penelitian ini menjadi salah satu dokumentasi kekayaan bahasa dalam budaya Minahasa.

Penelitian ini dilaksanakan di wilayah pemerintahan Provinsi Sulawesi Utara khususnya di daerah Minahasa. Untuk menunjang terlaksananya penelitian ini dengan baik, peneliti menentukan lokasi penelitian di wilayah Kecamatan Motoling Timur, Kecamatan Motoling Barat, dan Kecamatan Kumelembuai. Daerah ini dianggap layak dijadikan sebagai lokasi penelitian karena secara kuantitatif penutur bahasa Tontemboan di daerah ini masih cukup representatif. Alasan lain yaitu peneliti masih dapat menemukan tua-tua kampung yang memahami bahasa dan budaya Tontemboan.

$\%$

Populasi dalam penelitian ini adalah penutur bahasa Tontemboan dengan sampel penelitian yaitu penutur di Kecamatan Motoling Timur, Kecamatan Motoling Barat, dan Kecamatan Kumelembuai. Selanjutnya, peneliti memilih satu desa dari setiap kecamatan (kecuali Kecamatan Motoling Induk) dan desa-desa itu adalah desa Karimbow, desa Karimbow Talikuran untuk Kecamatan Motoling Timur. Di Kecamatan Kumelembuai peneliti memilih desa Kumelembuai Atas dan desa Kumelembuai Bawah, di Kecamatan Motoling Barat peneliti memilih desa Toyopon.

Penelitian ini menggunakan metode penelitian kualitatif dengan teknik wawancara. Data dianalisis dengan menggunakan metode deskriptif. Teknik analisis data dilakukan dalam tiga tahap yaitu sebelum di lapangan, selama di lapangan, dan sesudah di lapangan.

\section{Hasil Penelitian dan Pembahasan}

Nene $\square$ kundu 'nenek buyut', tete $\square$ kundu 'kakek buyut', nene $\square$ nenek', tete $\square$ kakek', apo $\square$ 'kakek atau nenenk buyut', amang 'ayah', bu $\square$ 'ayah', mom 'ayah', inang 'ibu', susi $\square$ 'ibu' mui $\square$ 'ibu', toyaang 'anak', luluna 'anak sulung', karuwa 'anak kedua', katelu 'anak ketiga', uner 'anak tengah', wo $\square$ bas 'anak bungsu', pakaka \an 'kakak' kaka? tuwama 'kakak laki-laki', bung 'kakak laki-laki', kaka' wewene 'kakak perempuan', ses 'kakak perempuan', tuwari 'adik', tuwari tuwama 'adik laki-laki', tuwari wewene 'adik perempuan', penana $\square$ an 'istri', kasule 'istri`, kalaley 'istri`, karapi ‘istri', ambalesa ‘suami istri`, poyo? 'cucu`, poyo? metuwari ‘sepupu dua kali', poyo? ang kundu `sepupu tiga kali', toya' ang metuwari 'sepupu satu kali', tanta 'bibi`, om 'paman', tuwa' 'paman 
atau bibi', muda? 'paman atau bibi', kasungkul 'besan', kalo 'ipar laki-laki atau ipar perempuan', kawuleng 'istri atau suami dari iparnya ego', paempo 'menantu laki-laki atau menantu perempuan', empo 'mertua laki-laki atau mertua perempuan', susi 'ipar perempuan', bu 'ipar laki-laki', pa $\square$ anaken 'keponakan', mekianak 'anak angkat atau anak adopsi'.

Berdasarkan taranak 'turunan', tete $\square$ kundu `kakek buyut' berada pada tataran tiga generasi di atas ego. Secara harafiah, kata kundu sebenarnya bukan bermakna buyut tetapi bermakna lutut. Kata kundu memiliki makna yang dalam dan khusus pada kata tete $\square$ kundu. Kata ini tidak sekadar bermakna lutut namun bermakna khusus bahwa seseorang yang berstatus sebagai tete $\square$ kundu memiliki tanggung jawab yang sangat besar terhadap taranaknya. Dia bukan orang sembarangan melainkan dianggap sebagai orang yang memiliki wewenang yang belum dapat dimiliki oleh generasi-generasi muda dalam taranaknya seperti memberkati orang, menasihati orang, memutuskan sesuatu hal atau masalah yang dianggap pelik dalam lingkup kerabatnya. Jadi, ibarat seseorang yang sedang berlutut, semua beban kekuatan yang dimiliki oleh masing-masing organ ataupun alat tubuh dalam dirinya, semuanya akan bermuara ke daerah lutut. Begitupun yang dimaksud oleh kata kundu dalam istilah tete $\square$ kundu, bahwa semua hal yang menyangkut urusan ataupun masalah keluarga dalam sebuah taranak, pasti tidak luput dari pantauan tete $\square$ kundu yang bersangkutan. Kalau sesuatu telah diputuskan oleh sang tete $\square$ kundu, tidak seorang pun yang dapat membantahnya. Bila dibantah, orang yang membantah itu dianggap orang yang kurang ajar, tidak tahu sopan santun, tidak taat terhadap orang tua, dan bisa mendapat kecelakaan. Dari penjelasan makna budaya yang dikandung oleh istilah tete $\square$ kundu, ia adalah seseorang yang dijadikan wakil Tuhan dalam taranaknya sebagai tempat meminta berkat, meminta restu.

Ibarat kata bijak surga ada di bawah telapak kaki ibu, begitupun yang berlaku untuk seorang nene $\square$ kundu. Dalam komunitas penutur bahasa Tontemboan, seorang nene $\square$ kundu memiliki tugas dan tanggung jawab yang besar terhadap keluarga dan taranaknya. Dia harus menjadi pendamping suami yang setia, ibu yang baik bagi anak-anaknya, dan figur ibu yang berwibawa dan bertanggung jawab terhadap taranaknya. Sekalipun sudah tua, peran seorang nene $\square$ kundu dalam keluarganya sangatlah berpengaruh. Artinya, sekalipun usia sudah lanjut dan mungkin secara fisik sudah tidak dapat diharapkan untuk melaksanakan 
tugas, tapi bila pikiran atau daya ingatnya masih baik dalam arti belum pikun, seorang nene $\square$ kundu masih dapat membuat aturan. Segala sesuatu yang tertuang dalam aturan yang dibuat oleh seorang nene $\square$ kundu, tidak seorang pun yang boleh membantahnya. Bila hal ini terjadi, yang melanggar aturan itu dianggap sebagai orang yang durhaka dan dapat celaka. Sampai sekarang fenomena seperti ini masih dipegang teguh oleh masyarakat di daerah ini. Mereka yakin dan percaya hal ini dapat terjadi dengan melihat kenyataan yang ada. Akibat sumpah dari nene $\square$ Kundu yang nota bene adalah orang tua-ibu, dewasa ini masih dipercaya dapat terjadi.

Selain istilah tete $\square$ kundu dan nene $\square$ kundu, masyarakat penutur bahasa Tontemboan juga mengenal istilah $a p o^{?}$. Istilah ini tidak dikenai pada jenis kelamin tapi pada tingkat umur ataupun generasi yang berumur panjang. Sekarang istilah apo $\square$ sudah mulai jarang didengar ataupun ditemui dalam budaya penutur bahasa Tontemboan karena sesuatu seperti berkurangnya generasi dalam sebuah taranak. Maksudnya, pada zaman dulu dalam sebuah taranak generasinya masih sempat mencapai tiga sampai empat generasi tapi dewasa ini dalam sebuah taranak sudah mulai sulit ditemukan taranak yang mencapai tiga sampai empat generasi. Lepas dari kenyataan yang ada, istilah ini masih dikenal luas bahkan masih digunakan oleh sebagian masyarakat penutur bahasa Tontemboan bila dalam taranaknya masih lengkap sampai generasi kakek buyutnya. Nilai budaya yang ada dalam istilah apo $\square$ adalah para anggota yang termasuk dalam taranak ini patut berbangga karena orang tua sampai taranak terakhir masih diberi kesehatan, kekuatan, dan umur panjang.

Dalam bahasa Tontemboan, Sang Pencipta disebut juga Amang Kasuruan yang berarti Tuhan Allah. Istilah amang sebagai nama terhadap ayah ada persamaan dalam hal sifat dari Tuhan Allah. Artinya, amang 'ayah' memiliki sikap kasih, mengayomi, panjang sabar, dan segala kebaikan seperti yang dimiliki oleh Amang Kasuruan. Sikap-sikap ini diperuntukkan hanya kepada orang-orang yang dikasihi dan disayangi dengan penuh cinta yaitu terhadap istri dan anak-anak atau keluarga. Itulah sebabnya, dalam keluarga Minahasa khususnya penutur Tontemboan, figur ayah sangat dihormati karena semua predikat kebaikan yang disandangnya.

Dalam bahasa Tontemboan, amang dapat dipanggil dengan Papa, Pa, nama kecil sang bapak, dan $b u \square$. Penyapaan dengan menggunakan bu $\square$ memiliki makna lain dari biasanya. Artinya, ada sesuatu yang sangat dipercaya bahwa anak-anak yang dilahirkan oleh 
sang ibu selalu bermasalah dalam hal ini selalu tidak berumur panjang ataupun selalu meninggal ketika lahir. Selain itu, anak-anak yang dilahirkan tersebut secara berturut-turut (dari anak pertama sampai terakhir) selalu mengalami hal yang sama yaitu meninggal. Hal ini dipercaya bahwa ada sisi yang bertolak belakang antara ayah dan anak yang dilahirkan. Siapa yang memiliki sisi paling kuat dari yang lain, dialah yang menang dan selalu sehat walafiat. Biasanya, sisi yang kuat selalu jatuh pada orang tua sehingga sang anak yang dianggap berada pada sisi yang lemah selalu mengalami sakit ataupun meninggal.

Inang dapat disapa dengan $m a m a^{?}, m a^{?}$ atau nama kecil dari ibu kandung oleh ego. Dalam komunitas penutur bahasa Tontemboan, inang dianggap sebagai seorang wanita terhormat. Sang inang memiliki tanggung jawab yang sangat besar dalam keluarga seperti melayani suami secara jasmani dan rohani, mengasuh dan membesarkan anak, menyelesaikan seluruh pekerjaan rumah tangga demi kenyamanan suami dan anak-anak.

Seperti istilah bu $\square$, istilah susi $\square$ juga menurut para informan memiliki makna lain yaitu ada unsur kepercayaan bahwa sang toya $\square$ ang 'anak' tidak boleh menyapa ibunya

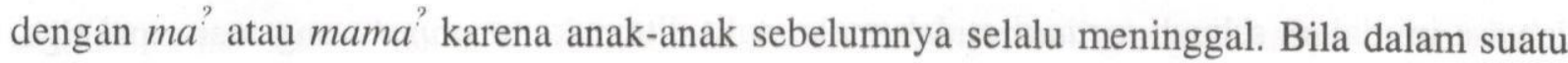
keluarga ada anak yang menyapa ibunya dengan nama kecil sang ibu, ini mengindikasikan ada sesuatu yang tidak normal dalam keluarga. Hal ini sangat dipercaya oleh sebagian besar masyarakat di daerah ini. Adapun budaya yang dimaksud berhubungan dengan kehidupan sang anak. Bila dalam satu keluarga anak-anak yang dilahirkan selalu meninggal saat bayi dalam arti baru menghirup udara di dunia dalam beberapa jam ataupun beberapa hari, maka anak tersebut meninggal. Fenomena seperti ini dianggap sebagai pembawa sial dalam keluarga. Kesialan ini dapat diatasi dengan beberapa cara seperti membuang anak tersebut dalam arti dipelihara oleh orang lain atau tetap dipelihara oleh orang tua kandung, namun anak tersebut diberi nama Buang atau Unggu $\square$. Cara ini dipercaya dan dianggap mujarab karena dapat menjadikan sang anak yang sakit-sakitan menjadi sehat-sehat dan umur panjang. Selain itu, penyapaan seperti ini muncul dikarenakan sang anak yang senantiasa diharapkan, secara berturut-turut selalu meninggal. Setelah keluarga menerapkan penyapaan ini terhadap sang inang, mulailah anak-anak yang dilahirkan selalu sehat dan berumur panjang sampai dewasa. Hal ini sangat dipercaya sampai sekarang oleh sebagian besar masyarakat di daerah ini. 
Toya $\square$ ang 'anak kecil' adalah istilah untuk anak-anak yang masih kecil dan berumur sekitar 1-12 tahun. Berbeda dengan istilah toya $\square$ ang dalam lingkup keluarga, istilah toya $\square$ ang dialamatkan juga kepada semua anak-anak, baik laki-laki maupun perempuan, baik balita, remaja, maupun dewasa termasuk yang sudah menikah. Mereka semua disebut toya $\square$ ang oleh ayah dan ibu mereka. Adapun dalam kebudayaan masyarakat Tontemboan, mereka mengenal istilah toya $\square$ ang seperti toya? ang luluna, toya ang karuwa, toya? ang katelu, dan seterusnya, sampai anak terakhir yang disebut toya' ang wo? bas. Setiap anak memiliki hak dan tanggung jawab yang berbeda ketika mereka sudah dewasa.

Seorang anak yang berstatus luluna 'sulung', biasanya memiliki tanggung jawab sejak dia masih kecil (namun sudah mengerti) yaitu dia harus mampu 'menjaga' adikadiknya ketika ayah dan ibunya pergi bekerja. Dia harus mampu menggantikan tugas ibunya bila ibunya pergi mencari nafkah membantu suaminya. Kebiasaan si sulung harus mengasuh adik-adiknya dikarenakan sang ibu sebagai wanita Minahasa memiliki karakter sebagai wanita pekerja. Mengenai hak dari luluna, dia memiliki hak istimewa. Sebagai pengemban kesulungan, ketika dewasa, dia berhak mengatur harta warisan dari keluarga mereka. Jika orang tua mereka telah meninggal, semua keputusan dari toya ang luluna tidak dapat diganggu gugat oleh adik-adiknya. Seorang toya ang luluna biasanya dianggap sebagai pengganti orang tuanya. Sebab itu, toya ang luluna harus bijaksana dalam mengambil keputusan. Dia akan dihormati dan disegani oleh adik-adiknya bahkan saudara-saudaranya yang lain jika dia mempu belaku adil dan dapat meredam kecemburuan di tengah-tengah saudara-saudaranya. Toya ang luluna biasanya disapa oleh adik-adiknya dengan sapaan pakaka?an.

Uner adalah istilah untuk memaknai anak tengah. Biasanya istilah ini berlaku pada keluarga yang memiliki tiga orang anak. Anak pertama disebut luluna dan anak bungsu disebut wobas sementara anak kedua atau anak yang diapit oleh si sulung dan bungsu disebut dengan istilah uner 'tengah'.

Wo' bas adalah istilah penamaan untuk anak terakhir atau anak bungsu. Tanggưng jawab anak wo bas hampir tidak ada. Anak yang berstatus wo? bas biasanya menjadi anak yang disayang oleh kedua orang tuanya. Dia mendapat perhatian ekstra dari kakakkakaknya. Wo'bas biasanya juga dikelompokkan menjadi dua yaitu wo'bas wewene dan wo bas tuwama. Kelompok anak yang distilahkan wo? bas wewene dikarenakan anak bungsu 
ini masih memiliki seorang adik atau lebih yang berjenis kelamin laki-laki. Sebaliknya, jika diistilahkan wo'bas tuwama, mengindikasikan bahwa anak bungsu tersebut masih memiliki seorang adik atau lebih yang berjenis kelamin perempuan. Mengenai hak dalam hal ini yang berhubungan dengan warisan, toya ang wo bas kadang-kadang mendapat agak lebih dari saudara-saudaranya yang lain seperti mendapat rumah yang ditinggali oleh ayah dan ibu mereka.

Masyarakat penutur bahasa Tontemboan memiliki budaya penamaan khusus terhadap anak-anak mereka karena sesuatu hal. Nama-nama yang dimaksud adalah Buang, Pitong, Unggu. Buang berarti dibuang karena masyarakat di daerah ini memiliki kepercayaan bahwa anak yang dimaksud tidak membawa kemujuran dengan kata lain membawa kesialan bagi dirinya sendiri. Anak seperti ini harus dinamai Buang sebagai tanda telah dibuang oleh keluarga dalam hal ini orang tua. Segala hal yang dianggap sial oleh keluarga ikut terbuang bersamaan dengan penamaan terhadap anak tersebut supaya anak ini beroleh kesehatan, keselamatan, dan umur yang panjang.

Pitong yang bermakna pungut adalah nama lain yang dialamatkan kepada anakanak yang dianggap tidak membawa kemujuran terhadap dirinya sendiri, orang tua, maupun keluarga. Anak yang selalu sakit-sakitan ataupun kakak-kakaknya selalu meninggal, harus dibuang terlebih dahulu kepada orang lain kemudian diambil dalam konteks dipungut punggu supaya anak yang dimaksud beroleh kesehatan, umur panjang, dan yang terpenting tidak meninggal seperti kakak-kakaknya. Jadi, seiring dengan pembuangan anak yang dimaksud, semua kesialan juga ikut terbuang. Nama Pitong dapat dinamakan kepada anak laki-laki maupun anak perempuan.

Selain dengan menamai Buang untuk anak-anak yang dianggap tidak mendatangkan kemujuran dalam keluarga, dapat juga dinamai dengan nama Unggu. Unggu berarti punggu-pungut. Seperti halnya fenomena penamaan dengan menggunakan nama Pitong, nama Unggu diberikan pula kepada anak yang selalu sakit-sakitan ataupun kakak-kakaknya selalu meninggal. Keyakinan masyarkat di daerah ini, anak tersebut harus dibuang terlebih dahulu kepada orang lain kemudian diambil dalam konteks dipungut (punggu) supaya anak yang dimaksud beroleh kesehatan, umur panjang, dan yang terpenting tidak meninggal seperti kakak-kakaknya. Nama Unggu hanya dikhususkan pada anak perempuan. 
Istilah pakaka' an 'kakak' dalam budaya penutur bahasa Tontemboan dikenal dalam dua istilah yaitu kaka? tuwama dan kaka? wewene. Kaka? tuwama dalam budaya masyarakat ini memiliki tanggung jawab yang besar terhadap keluarga dan adik-adiknya. Seorang kaka' tuwama harus dapat melindungi adik-adiknya dari gangguan orang lain. Sikap ini sudah mulai ditanamkan sejak mereka masih kecil. Biasanya sorang $\mathrm{kaka}^{\text {? tuwama }}$ harus dapat menjaga adik-adiknya ketika ayah dan ibunya mencari nafkah. Dia harus dapat memasakkan makanan untuk adik-adiknya, menjaga mereka supaya terhindar dari segala macam kecelakaan. Setelah dewasa, biasanya yang dianggap sebagai kaka? tuwama memiliki hak khusus terhadap harta warisan yang dipercayakan oleh orang tua mereka. Bila orang tua sudah meninggal dan masih ada lagi harta warisan yang belum dibagi, biasanya kaka? tuwama memiliki hak penuh terhadap siapa harta warisan itu diberikan. Hal ini dilakukan oleh kaka? tuwama karena secara konvensional, dia adalah ahli waris dalam keluarganya. Selain itu pula, kaka? tuwama biasanya mendapat harta warisan yang lebih banyak dari saudara-saudaranya yang lain. Istilah $k a k a$ ' wewene 'kakak perempuan' menurut budaya penutur bahasa Tontemboan, memiliki tanggung jawab yang besar pula terhadap keluarga. Dia harus dapat membantu keluarga khususnya yang menyangkut keperluan dalam rumah tangga. Dia juga dapat mencari nafkah membantu kedua orang tuanya. Sehubungan dengan harta warisan, $k a k a ?$ wewene tidak memiliki hak istimewa seperti kaka'tuwama. Walaupun dia banyak membantu keluarga, tetapi mengenai harta warisan, dia harus menurut dan menerima apa adanya sesuai dengan yang telah diputuskan oleh sang pewaris.

Ses adalah sebutan ego terhadap kakak perempuan. Sebutan ini dianggap sopan dan akrab. Hubungan antara ses dan ego biasanya terbuka dan bebas.

Selain digunakan untuk menyapa adik kandung, tuwari dapat pula digunakan untuk menyapa orang lain dengan bentuk patuwari yang berarti yang dijadikan saudara. Hubungan tuwari dengan ego sangat baik dan mesra. Mereka saling menyayangi, menghormatituwari sangat hormat dan santun kepada ego, sebaliknya ego sangat memperhatikan kehidupan dan keselamatan sang tuwari. Adapun komunitas penutur bahasa Tontemboan ketika berinteraksi, akan mengelompokkan saudara jenis tuwari ini dengan menyebut tuwari tuwama dan tuwari wewene. Kalau sudah dikelompokkan seperti ini, istilah tuwari tuwama dan tuwari wewene tidak akan digunakan lagi sebagai sapaan. Dalam komunitas 
penutur bahasa Tontemboan, biasanya tuwari tuwama dalam keluarga menjadi salah satu anak kesayangan. Bila dia merupakan anak bungsu dalam keluarga, pastilah tuwari tuwama tersebut diposisikan sebagai anak kesayangan. Dalam pembagian harta pun tuwari tuwama selalu diperhitungkan, dia dapat mendapat warisan lebih dari kaka? wewene ataupun tuwari wewene. Dalam keluarga, biasanya tuwari wewene selalu menempati posisi sebagai anak kesayangan dari ayah dan ibu apa lagi di mata sang ayah. Dia diperlakukan bak telur yang mudah pecah. Oleh sebab itu, tuwari wewene senantiasa diusahakan oleh kedua orang tua mereka dapat terlindungi dari segala hal yang dianggap tidak baik dan berbahaya. Dalam pembagian warisan pun, dia dapat mendapat lebih walaupun tidak sebanyak yang didapat oleh kaka? tuwama atau tuwari wewene.

Secara leksikal, penana an terdiri dari morfem dasar tana? dan afiks pembentuk kata benda-pe-an. Makna morfem tana ${ }^{\text {I }}$ tanah, ${ }^{2}$ masak-memasak. Makna pertamatanah, ketika dianalisis berdasarkan istilah kekerabatan, masih signifikan dengan makna suami atau istri. Artinya, makna tana? ditambah afiks -an menjadi tana an, bermakna ratakan. Kata ini memiliki makna budaya yaitu tanah yang bergunung ataupun berlubanglubang, secara bersama-sama antara suami dan istri meratakannya untuk keperluan rumah tangga yaitu untuk kesejahteraan rumah tangga, untuk membangun tempat tinggal keluarga. Makna kedua masak-memasak, mendapat afiks pe-an menjadi penana?an. Kata penana an terdiri dari dua morfem yaitu tana? yang bermakna masak-memasak, dan pean yang berfungsi sebagai afiks pembentuk kata benda. Setelah morfem tana? mendapat afiks pe-an, maknanya bukan sebagai masakan lagi tapi berubah menjadi suami. Penana?an yang bermakna suami memiliki makna budaya sebagai seorang laki-laki dewasa yang benarbenar bertanggung jawab terhadap keluarganya dalam hal ini terhadap istri dan anak-anak. Tanggung jawab yang dimaksud dalam konteks ini adalah mampu menafkahi istri secara batiniah dan badaniah, juga menyayangi dan mencintai sang istri sampai kapanpun sesuai ikrar dalam perkawinan. Selain itu, tidak pernah berpikir apalagi menduakan cinta sang istri. Bertanggung jawab terhadap anak-anak berarti mampu menafkahi dalam hal ini membesarkan-menghidupi-dan memberikan pendidikan yang layak terhadap mereka.

Makna lain dari penana? an dialamatkan kepada wanita yang berstatus sebagai istri. Penana an dianggap pula sebagai pendamping suami yang bertanggung jawab terhadap keluarga, dan mampu menyenangkan sang suami setiap hari. Istri yang baik adalah 
perempuan yang mampu menyiapkan kebutuhan sang suami ketika akan ke tempat kerja, menyediakan sarapan untuk suami dan anak-anak sebelum mereka mulai beraktivitas, dan menyediakan makan siang juga makan malam secara rutin. Sebagai penana?an, sang istri harus mampu mengurus dan membesarkan anak-anak dengan penuh kasih sayang dan tanggung jawab.

Penana' an 'istri' dapat disapa dengan mamana, mamaera, kalaley, atau karapi oleh ego dalam hal ini suami. Sapaan mamana berbeda dengan sapaan [mamaera] dari segi fungsi dan arti. Secara etimologi, mamana terdiri dari dua morfem yaitu morfem mama 'ibu' dan na 'nya'. Na pada morfem mama merujuk pada seorang anak. Artinya, mamana adalah sapaan khusus terhadap istri yang hanya memiliki seorang anak. Begitupun untuk istilah mamaera 'ibu mereka-ibunya anak-anak', terdiri dari morfem mama 'ibu' dan era singkatan dari sera 'mereka' yang merujuk kepada anak-anak. Jadi, sapaan mamaera yang bermakna ibunya anak-anak, khusus ditujukan pada istri yang memiliki anak lebih dari satu.

Selain istilah penana? an, komunitas penutur bahasa Tontemboan mengenal pula istilah kasule 'suami' atau 'istri'. Secara etimologi, kasule adalah derivasi dari kata dasar sule 'topang, ganjal, sangga' kemudian diberi partikel $k a$ sebagai pembentuk kata benda. Jadi, makna awal dari istilah kasule adalah teman penopang dalam kehidupan berumah tangga. Agak berbeda dengan makna budaya yang dikandung dalam istilah penana? an, makna budaya yang dikandung dalam istilah kasule adalah baik sang istri maupun sang suami, haruslah memiliki rasa solidaritas yang tinggi, kebesaran jiwa untuk menunjang pasangannya dalam segala hal. Contoh, ketika sang suami mengambil sebuah keputusan sekaitan dengan perihal rumah tangga, sang istri harus menopang keputusan sang suami. Begitu pula dalam berkarir, apapun pekerjaan suami, sang istri haruslah menopang, mendorong, memberi motivasi, supaya kehidupan rumah tangga yang dibangun bersama semakin hari semakin baik. Sebaliknya, demikian juga sang suami memperlakukan istrinya seperti pada penjelasan di atas, karena secara umum, budaya Minahasa-termasuk dalam komunitas Tontemboan-para wanita suka “bekerja” (berkarir), mencari nafkah untuk membantu suami.

Kalaley 'yang disayang' adalah sapaan suami terhadap istri atau sebaliknya sapaan istri terhadap suami. Sapaan kalaley biasanya digunakan oleh sang istri ataupun sang suami terhadap pasangannya di belakang anak-anak. Mereka lakukan hal ini karena sapaan kalaley 
memiliki makna mesra ibarat sepasang kekasih yang masih berpacaran. Sebenarnya, sapaan kalaley digunakan oleh suami terhadap istri dan istri terhadap suami sejak masa pacaran. Pada masa itu, antara laki-laki dan perempuan telah memiliki jalinan cinta yang serius dan saling mencintai, sehingga mereka sepakat saling menyapa dengan istilah kalaley. Selain dasar ini, penyapaan kalaley dilakukan pula pada saat sepasang kekasih ini bercanda. Penyapaan seperti ini terbawa sampai mereka berdua berumah tangga.

Karapi 'teman' adalah sapaan suami terhadap istri atau istri terhadap suami. Pengertian dan penerapan sapaan karapi ini sama persis dengan sapaan kalaley antara suami istri atau antara sepasang kekasih yang belum menikah tapi telah memiliki hubungan khusus dan telah diketahui oleh orang tua mereka. Karena hubungan mereka serius dan telah diketahui oleh masing-masing orang tua mereka, menyebabkan hubungan mereka kadang seperti teman. Dalam budaya kerabat penutur bahasa Tontemboan, hubungan ego dengan poyo? berarti sepupu dua kali atau sepupu tiga kali. Istilah poyo? ada dua macam yaitu poyo? metuwari 'cucu' (sepupu dua kali) dan poyo' ang kundu 'cece'(sepupu tiga kali). Hubungan ego dengan poyo? metuwari adalah sepupu dua kali, baik untuk laki-laki atau perempuan dari pihak ayah maupun pihak ibu. Seperti hubungan yang ada pada tataran poyo? ang kundu, hubungan yang terjadi juga pada tataran poyo? metuwari sangat baik", bahkan biasanya lebih baik dan lebih dekat daripada hubungan poyo? ang kundu. Berdasarkan taranak, hubungan ego dengan poyo? ang kundu adalah sepupu tiga kali, baik untuk laki-laki atau perempuan dari pihak ayahnya ego maupun dari pihak ibunya ego. Hubungan kekerabatan yang ada antara poyo? ang kundu ini biasanya sangat baik. Mereka merasakan bahwa mereka seperti kakak adik sekandung. Toya? ang metuwari adalah sepupu satu kali antara ego dengan saudara laki-laki atau saudara perempuan dari pihak ibu atau pihak ayah. Hubungan yang terjadi di antara anak-anak yang posisinya pada tataran toya ang metuwari adalah hubungan yang paling dekat dan familiar dari semua hubungan sepupu yang ada. Di antara mereka kerap seperti kakak beradik sekandung saja. Aktivitas sehari-hari kadang dilakukan dalam satu rumah dari salah satu orang tua mereka. 'Kebebasan' yang tercipta antara mereka biasanya sangat kental dan 'bebas'.

Tanta 'bibi'-nya ego dari pihak ayah ataupun dari pihak ibu biasanya dipandang kurang lebih sama kedudukannya dengan posisi ibu kandung. Karena kedudukan tanta baik dari pihak ayah maupun pihak ibu kurang lebih sama dengan kedudukan sang inang,

$102 \mid$ KADERA BAHASA (Jurnal Ilmiah Kebahasaan dan Kesusasteraan) 
biasanya tanta dapat mengambil alih tugas ibu kandung seperti mengasuh anak-anak dan membereskan pekerjaan dalam rumah tangga (mencuci, memasak) ketika sang inang beraktivitas di luar rumah. Hubungan antara anak-anak dan tanta juga sangat baik dan 'bebas'. Kadang kala di antara mereka saling berbagi cerita baik layaknya inang dan toya $\square$ ang. Anak-anak sebagai keponakan akan merasa selalu dijagai dan dilindungi dari segala hal yang tidak baik dan mencelakakan. Sebaliknya, tanta sebagai bibi merasa memiliki tanggung jawab yang besar terhadap keselamatan keponakan ketika orang tua mereka tidak bersama dengan mereka. Kadang kala secara spontan, seorang tanta akan berlaku layaknya inang terhadap para keponakan ketika keponakan mengalami sesuatu masalah.

Secara taranak, hubungan ego dengan om seperti anak dan orang tua karena om adalah kakak atau adik laki-laki dari ibu atau ayahnya ego. Seperti hubungan yang terjadi antara keponakan (ego) dan bibi, seperti itu pula yang terjadi antara keponakan (ego) dan paman. Seorang om biasanya memiliki wibawa yang lebih tegas dibandingkan dengan seorang tanta.

Tuwa? adalah kakak laki-laki atau kakak perempuan dari ayahnya ego atau ibunya ego. Seperti halnya hubungan antara ego dengan om dan tanta, seperti itu pula hubungan antara ego dan tuwa? ${ }^{\text {? }}$ Biasanya dalam hubungan ini, yang menjadi seorang tuwa? selalu menjaga wibawanya dengan cara selalu memberi nasihat pada setiap kesempatan. Keponakan ego yang dinasihati biasanya tidak akan membantah.

Muda? adalah adik laki-laki atau adik perempuan dari ibu atau ayahnya ego. Hubungan yang terjadi antara muda? dan ego biasanya seperti teman. Mereka biasanya berbagi cerita apapun karena merasa lebih dekat dan lebih banyak memiliki persamaan dalam memandang hidup ini.

Kasungkul adalah orang tua dari dua orang dewasa (ego dan istri atau ego dan suami) yang sudah menikah. Kedua orang tua dari masing-masing anak diposisikan sebagai orang yang berbesanan. Secara etimologi, kasungkul terdiri dari bentuk $k a$ 'ketika' dan bentuk sungkul 'temu-bertemu'. Dalam bahasa Tontemboan, bentuk ka 'ketika' digolongkan sebagai partikel penyambung atau lebih dikenal dengan istilah konjungtor. Jika dianalisis dari arti ka dan sungkul, maka istilah kasungkul akan berarti ketika bertemu. Arti sebenarnya yang dikandung dari istilah kasungkul 'ketika bertemu' ini, sebenarnya tidak 
jauh berbeda dengan makna budaya yang ada di dalamnya. Kasungkul, adalah istilah untuk memaknai orang-orang yang menjadi besan dalam satu keluarga yang dipertemukan oleh anak-anak yang menikah. Orang-orang yang berbesanan ini tidak menjadi besan dengan cara direncanakan tapi menjadi besan karena kebetulan dipertemukan oleh anak mereka masing-masing. Setiap besan secara spontan merasa memiliki tanggung jawab yang besar terhadap anak-anak mereka. Misalnya, menampung anak-anak mereka pada masa-masa awal perkawinan sekaligus memberi makan karena anak-anak mereka dianggap baru mulai belajar mencari nafkah. Malahan, ada rumah tangga muda yang dinafkahi sampai mereka memiliki anak pertama. Sepanjang keluarga muda ini belum benar-benar mandiri, para besan bergiliran menampung sambil membantu menafkahi mereka. Adapun sapaan yang digunakan di antara besan ini adalah Bu dan Susi. Sapaan ini dinggap sapaan yang sangat sopan.

Secara etimologi, ambalesa dibentuk dari tiga morfem yaitu $a$ 'di' (dalam bahasa Tontemboan, jika partikel $a$ 'di' mengikuti kata dasar yang huruf pertamanya adalah konsonan $w$-wale, maka kata tersebut akan mengalami alomorf menjadi mb + wale 'rumah' + sa dari kata esa 'satu', terjemahannya adalah di rumah satu-dalam satu rumah - serumah. Jadi, maksudnya adalah orang-orang yang hidup di satu rumah dalam hal ini suami dan istri. Sebagai ambalesa, mereka tidak boleh hidup terpisah, dan tidak mengenal istilah pisah ranjang dalam keadaan apapun. Istilah ambalesa ini memiliki pula nilai rasa bahwa orang lain yang melihat kehidupan rumah tangga mereka selalu harmonis.

Kalo adalah kakak laki-laki, kakak perempuan, adik laki-laki, adik perempuan dari istri atau suami dari ego yang bermakna kakak ipar atau adik ipar. Makna budaya yang terkandung pada istilah ipar adalah kakak atau adik dari sang suami atau sang istri; memiliki aturan-aturan secara konvensional dalam masyarakat budaya Tontemboan seperti tidak boleh menyapa dengan nama, harus bersikap sopan dalam tutur kata antara yang satu dengan yang lain.

Kawuleng adalah kata yang terdiri dari morfem wuleng yang bermakna pikul dan afiks $k a$ - yang bermakna ketika. Secara leksikal, kawuleng bermakna ketika pikul namun secara harafiah memiliki makna budaya bahwa ego dan istri atau suami dari pasangan ego (penana 'an) sama-sama merasa sepenanggungan dan senasib dalam hal melaksanakan tanggung jawab terhadap keluarga besar (istri, anak, ipar, mertua) mereka. Tanggung 
jawab dalam konteks ini bukan berarti sekadar memberi perhatian secara materil namun cenderung memberi perhatian secara moral pula. Hubungan antara mereka selalu dijaga sebaik mungkin dalam situasi dan kondisi apapun.

Paempo terdiri dari kata empo 'mertua' dan partikel pa yang berfungsi sebagai pembentuk kata benda. Jadi, paempo berarti 'yang dijadikan mertua', namun yang dimaksud dalam konteks ini adalah menantu bukan mertua. Paempo adalah sebutan untuk seorang menantu perempuan dan menantu laki-laki. Seseorang yang dijadikan paempo harus sopan dan berbakti terhadap emponya, karena sejak resmi menjadi istri atau suami dari pasangannya, suami atau istri tersebut sudah dianggap seperti anak sendiri 'anak kandung' oleh orang tua kandung dari pasangannya. Sebab itu, seorang paempo harus dapat melayani orang tua dari pasangannya dalam keadaan apapun. Seorang paempo yang tidak dapat melakukan hal ini akan dianggap empo yang tidak sopan, tidak tahu diri, dan pada akhirnya tidak akan dihargai dalam taranak pasangannya. Paempo biasa disapa dengan nama diri jika mereka belum memiliki anak. Sebaliknya, jika telah memiliki anak, akan disapa dengan mama+nama anak atau papa+nama anak. Bila anak mereka sudah lebih dari satu, maka sapaan terhadap paempo akan menggunakan nama anak tertua.

Empo yang bermakna 'mertua' adalah sebutan untuk ayah atau ibu dari istrinya ego. Orang yang dianggap sebagai lempo/ haruslah dapat menjaga sikap, sopan terhadap menantunya, supaya dia akan dihargai dan dihormati. Empo laki-laki tidak boleh bersikap bebas terhadap paempo perempuan, sebaliknya paempo perempuan tidak dapat bersikap bebas terhadap empo laki-laki. Bila aturan ini dilanggar baik secara sadar maupun tidak, dapat menimbulkan imajinasi negatif pada orang lain yang kebetulan melihatnya.

Susi adalah istilah untuk ipar perempuan. Cara pelafalannya tanpa penekanan di bagian belakang. Hubungan susi dan ego cukup baik, santun, saling menghormati, dan saling menghargai. Kadang kala ego secara spontan dan tulus melindungi sang susi dari segala bentuk gangguan, sebagaimana ego melindungi istrinya.

$B u$ adalah ipar laki-laki dari ego. Seperti halnya susi, $b u$ adalah sapaan yang dianggap sopan terhadap ipar laki-laki. Pelafalannya pun sama, tidak ada penekanan di belakang istilahnya. Hubungan ego dengan $b u$ senantiasa dijaga kelanggengannya. Di antara mereka selalu saling menghormati, menghargai. Kadang kala, hubungan mereka seperti 
teman atau sahabat; duduk bersama berbagi cerita, bertukar pandangan dan pengalaman hidup sehingga hubungan mereka tetap baik dan terjaga.

$P a$ ?anaken adalah anak dari kakaknya ego, anak dari adiknya ego. Hal ini berlaku pula pada taranak istrinya ego atau suaminya ego. Biasanya istilah pa? anaken ditujukan pada generasi pertama sesudah ego. Baik laki-laki maupun perempuan tetap diistilahkan sebagai pa? anaken. Sikap pa? anaken terhadap ego sebagai orang tua, harus selalu sopan, menghargai, dan patuh. Bila sikap-sikap seperti ini dilanggar, biasanya hubungan antara pa'anaken dan ego akan terganggu bahkan dapat merembet pada hubungan ego dan orang tua dari pa? anaken.

Mekianak adalah anak yang diadopsi oleh satu keluarga. Biasanya yang dijadikan anak angkat adalah anak saudara sendiri ataupun anak dari kerabat dekat. Perihal mekianak dipercaya sebagai salah satu cara untuk pemancing bagi pasangan yang sulit mendapat anak ataupun pasangan yang sudah lama menikah tapi tidak kunjung dikaruniai anak. Mereka akan memelihara anak yang diadopsi ini dengan penuh kasih sayang, mendidik dengan benar, supaya mereka boleh beroleh anak yang baik pula.

\section{Simpulan}

Masyarakat penutur bahasa Tontemboan mengenal dan menggunakan istilah-istilah kekerabatan berdasarkan kekerabatan hubungan darah, kekerabatan perkawinan, dan kekerabatan tambahan.

Istilah-istilah kekerabatan yang digunakan dalam komunitas penutur bahasa Tontemboan ada yang berfungsi sebagai:

a. sebutan kekerabatan hubungan darah, sebutan kekerabatan perkawinan, dan sebutan kekerabatan tambahan.

b. Sapaan kekerabatan hubungan darah, sapaan kekerabatan perkawinan, dan sapaan kekerabatan tambahan.

c. Sebutan sekaligus sapaan kekerabatan hubungan darah, sebutan sekaligus sapaan kekerabatan perkawinan, dan sebutan sekaligus sapaan kekerabatan tambahan.

$106 \mid$ KADERA BAHASA (Jurnal Ilmiah Kebahasaan dan Kesusasteraan) 
Sebagian besar istilah kekerabatan yang digunakan oleh komunitas penutur bahasa Tontemboan, baik yang dikelompokkan sebagai sebutan, sapaan, maupun sebutan sekaligus sapaan; memiliki makna budaya.

\section{DAFTAR PUSTAKA}

Alwasilah, Chaedar. A. 2007. Sosiologi Bahasa. Bandung, Angkasa.

Badudu, J.S. 1979. Pelik-Pelik Bahasa Indonesia. Bandung, Pustaka Prima.

Casson, W. 1981. Language, Culture, and Cognition. New York, Macmilan Publishing Co. Inc.

Foley, A. 1997. Anthropological Linguistics: An Introduction. Oxford England, Blackweel Publisher Inc.

Fox, 1967. Kinship and Mariage: An Anthropological Perspective. England, Penguin Books.

Koentjaraningrat. 1990. Manusia dan kebudayaan di Indonesia. Jakarta, Djambatan.

Kridalaksana, H. 2001. Kamus Linguistik. Jakarta, PT Gramedia.

Leech, 2003. Semantik. Yogyakarta, Pustaka Pelajar.

Rahardi, 2009. Bahasa Prevoir Budaya. Yogyakarta, Pinus Book Publisher. 2006. Dimensi-dimensi Kebahasaan: Aneka Masalah Bahasa Indonesia Terkini. Jakarta, Erlangga.

Redaksi Kawan Pustaka. 2004. Undang-Undang dan Perubahannya. Jakarta, Kawan Pustaka.

Spradley, P. J. 1997. Metode Etnografi. Yogyakarta, PT Tiara Wacana Yogya.

Sugiyono. 2005. Memahami Penelitian Kualitatif. Bandung, Alfabeta.Sugono. 2008. Kamus Besar Bahasa Indonesia. Jakarta, Balai Pustaka.

Thomas, L. dan Wareing, S. 2007. Bahasa, Masyarakat dan Kekuasaan. Yogyakarta, Pustaka Pelajar.

Wenas, 2007. Sejarah dan Kebudayaan Minahasa. ---- Institut Seni Budaya Sulawesi Utara. 